\title{
Backyard Ethnography: Defamiliarizing the Familiar and Understanding the Consumer
}

\author{
Inga Treitler \\ Anthropology Imagination LLC
}

\begin{abstract}
This is a paper about how observers can work "in home communities" without succumbing to comfortable assumptions that can be blinding to insights. Stories are presented from three author conducted ethnographies; from workshops that trained participants to conduct interviews; and from client shadows. The standard risks of backyard ethnography are countered with tips on breaking down preconceptions. Like the author's backyard ethnographies, client and respondent collaboration in ethnography depend on the art of defamiliarizing presumptions and dogma. Business anthropology can gain from bringing clients to the field and from engaging respondents to do ethnography. These collaborations can eventually integrate consumer perspectives throughout an organization.
\end{abstract}

"An object is not so attached to its name that one cannot find for it another which is more suitable." René Magritte (1929)

\section{INTRODUCTION}

The truly unfamiliar does not exist - not for long anyway. Magritte delighted in challenging the public through his art to defamiliarize familiar things. An everyday object, a pipe, say, is not what we think it is [ceci n'est pas une pipe]. To challenge our assumptions, he suggests, is to bring new depths of thought, if not knowledge (Cembalest, 2012). Mental model theory, which informs much of the analysis in this paper, teaches us that both too much familiarity and too little familiarity can be blinding. This is a paper about several ways that observers can work with the familiar without succumbing to the comfortable assumptions that can obscure what is in front of us to be seen and experienced. "Untamed subjectivity," writes a sociologist of education "mutes the emic voice" (Peshkin, 1988:21). As his work suggests, the literature on how we shape our research through the facts of our life experiences, is broad, not restricted to anthropology, and serves a range of topics and applications, from theory to increasing arenas of practice. In the arenas of practice is where this paper is situated in hopes of stimulating a conversation about how to bring consumers more into the research and how to continue to engage clients as collaborators in research. The last twenty years have seen many breakthrough technologies and methods, from the simple pencil and paper to the sophisticated applications of information technology for bringing consumers and clients into research. Many of these state of the art developments can be found in the proceedings of the Ethnographic Praxis in Industry Conference (see for example EPIC2013's session, (Co)creation and (Co)participation: multiple actors in research epiconference.com).

Backyard ethnography is not, to say the least, a neglected topic, as has been noted in van Maanen (2011) in what he calls the proliferation of adjectival anthropology. There's an established and rich 
literature on native anthropology, insider anthropology, native anthropology, feminist anthropology, reflexivity, positionality, and studying up, all of which involve working in familiar environments and questioning the researcher position in shaping understandings. Issues addressed concern cultural identity, power, race, oppression, privilege. Though these questions will never be irrelevant in any ethnographic encounter the driving concern for this essay is to anchor an understanding of how to preemptively minimize bias that may interfere with perception of critical differences among mental or cultural models (I use the terms mental model and cultural model interchangeably; I avoid cognitive model though the theoretical foundations are from cognitive and psychological anthropologists).

The theoretical foundations that shape this paper have roots in cognitive anthropology and mental model theory and that comes with a particular focus on the science of perception and communication, and these are addressed in a section on deconstructing participant observation. The remainder of the paper is structured as follows. First, three kinds of backyard ethnography are presented, with examples from each. The largest portion of the discussion is on the very immersive and personal experience of my community interviews. I give greater attention to those vignettes because the researcher point of view is mine, so I have access to the subjectivity and biases, whereas the cases for consumer as ethnographer and the client as ethnographer are about the mechanics of creating space for these collaborations with cautionary notes about the risks for bias. In those cases we had only limited ways to train the collaborators to be alert to their own biases. That topic is taken up again in the final section of the paper. Second I recapture and deconstruct the elements of traditional participant observation because that is the point at which our ideologies and our own mental models stand to influence not just our field interactions but what we notice and what gets recorded. The final section is about how parties within organizations can use the defamiliarization tips to explore their own assumptions about their products, to integrate the consumer interests into thinking about their products, and as is a pattern on the rise in organizational transformation, to include diverse internal perspectives on the products and on the organization itself.

\section{THREE KINDS OF BACKYARD ETHNOGRAPHY}

First, we anthropologists can, and increasingly do, counter to orthodoxy, study close to home. In fact it's not terribly new, in the sense that even the traditional Malinowskian method of participant observation rested on the pillars of "rapport" and "entrée" key components of recreating a "homelike" context. In the "Community Ethnography" section three vignettes from the mental models interviews about learning are presented. Second, the respondent can be the ethnographer - the ultimate insider, using their eyes and ears and senses and perceptions to frame and collect the story and share it with the anthropologist. In this section I describe a pioneering undertaking for the US Department of Energy that involved paying recipients in an entitlement program to interview their friends and family to collect remembered stories about the program. And finally, researchers can take the client into the backyard with them. For this section I describe collaboration with a fast food client who shadowed the ethnographer.

\section{Community Ethnography}

As van Maanen intones in his 2011 edition of Tales of the Field, "backyard ethnography has not often had the approval of priests" though, he goes on to note, "change is afoot." And so it is. About a year ago, I was invited to interview some "ordinary Americans" to hear their opinions on what they think is important to learn, and how they think learning best takes place. Selection criteria excluded educators or those involved in education policy, but were otherwise a broad cross section of ages, gender, and occupations. The client is the Frameworks Institute; a Washington DC based non profit group that does applied communications research for policy makers and members of the general public (frameworksinstitute.org). I mention their name with permission, but the interviews summarized in the vignettes are anonymized. The client's recruiter contacted me and together we looked at some local recruiting agencies, and I made some phone calls and then selected one that seemed well situated to meet our needs. The client provided the recruiting parameters and then the recruiter and I reviewed the list of respondents together to make sure they fit the goals of the interviews. All the other interviews around the 
country and in several non US countries are held in public places like malls, cafes, restaurants. The interviews are long enough that it's nice for the participant to be able to get a drink or a bite to eat if it's meal time. I selected a Starbucks in a central location, easy for people from outside the central city to find quickly, but a Starbucks where I don't go that often so there would be little risk of someone coming by who I know. The goal of the interviews was to construct cultural models of tacit knowledge. The analysis will be presented to other nonprofits and policy makers to help them articulate messages that will be better understood by the public because they use familiar mental models. Interviews were conducted in several communities around the United States, each ethnographer doing interviews in their own communities.

\section{Community Ethnography's Upsides}

Backyard ethnography allows projects to economize on time, energy, and emotions. Researchers have greater control over recruitment and build on local community knowledge. Backyard ethnography allows researchers to share points of reference with the research participant (landmarks are familiar, local personalities are known). For example, in the conversations about education I was interested in nonclassroom learning, and respondents made reference to places, events, and issues that I am familiar with: Ijams Nature Center (pronounced iyams), the World's Fair Park, Dollywood, trails in Smoky Mountain National Park, schools, fan-dom for the UT Vols, unequal access to the Internet in classrooms. Because the interviews were transcribed and the analysis was not done by me, I had to be sure that the participant explained what was important to them about each point of reference. That part of the interview turned into a helpful device. The particular combination here of interviews by a community member and analysis by a non community member who also had no access to nonverbal cues, created something of an additional safeguard against insinuating bias.

\section{Community Ethnography's Downsides}

Asking for clarification and contextual and surrounding detail in an interview, is absolutely standard, especially when looking for particular language, terms, turns of phrase, and the sorts of things that will reveal an underlying mental model - that point where things feel different and noteworthy, possessing a kind of theretofore unrecognized logic where our deeper questioning and circling around will be focused. But the prompts and probes are easier and more egalitarian when it comes from a place of really not knowing. So asking the question on behalf of the "unfamiliar" analyst who would only have transcribed interview notes (not even tape) to go by, that was useful. It also helped me not plough through assuming that because of shared references I understood the underlying meanings and values. Shared references can in fact be dangerous. They are not the same as shared experiences. It is easy to fall into a patter about Smoky Mountain trails, special events at Ijams. Stepping back and asking the respondent to speak to the remote analyst gave them a chance to really frame the reference according to what's important to them. It helps them articulate tacit knowledge and unconscious assumptions. The difficulty of objectivity is a recurrent theme in anthropology (e.g., Clifford and Marcus, 1986) and the risks of backyard ethnography are rooted in anthropology's canon. So here I am in a small community, facing down those risks.

Here's the context of the community ethnographies. Knoxville is a city of 200,000 , with a county population of nearly 0.5 million that speaks to an urban - suburban split, and many small, rural, isolated towns across the Tennessee Valley whose populations are dependent on Knoxville for commerce and medical facilities. By those figures it counts as a large city in the U.S., where average city size is 100,000. But its history and its valley geography has left it a segregated place where people live in small town style within individual communities. I hasten to add that small town living in big cities of the world is not unusual. Who says it better than the little boy of privilege from NYC's Upper East, one of the world's highest rent districts in The Nanny Diaries? "The Museum of Natural History?" he gasps? "That's on the West side, isn't it? Mommy says never go on the West Side!" McGlaughlin and Kraus, 2003). Small town living anywhere poses challenges for backyard ethnography. For example, over the 25 years I've lived in Knoxville the degrees of interpersonal separation have shrunk, even though local lore still names me a "damn Yankee" - that's the kind who comes from up north and never goes away. But even though "my 
people" aren't from here and I don't have a church, or maybe because of that, it does not take long to find common acquaintances. I list the degrees of separation as a downside, or maybe a potential obstacle is a better way to put it, because of the experience of Case \#2 in the next section. Finding common acquaintances with the respondent in that interview gave me a feeling of camaraderie. Nice. But ethnographically risky. I felt we shared cultural models but to presume we did would, as Peshkin (1988) put it, "mute the emic voice."

The ethnography consists of eight 90 minute interviews. The structure of the interview and the style of questions were prepared by the researchers at Frameworks, the client. The theoretical underpinnings of the survey design is from early cognitive anthropological and linguistic theory of cultural models (for example, Jackendoff, 1985; Holland and Quinn, 1987; Keller and Keller, 1996). The style of our conversations allow the participant's natural language, phrasing, timing, hesitations, tones of voice, and non verbal enunciations like laughter to be part of the analysis, as captured in the transcription. The interviewer is not the person responsible for analyzing the transcripts and for reconstructing the cultural models. That is done by two other researchers and whose articulation of posited cultural models are discussed and then articulated as core cultural models. The idea is to find a way to identify from the general public, deeply held core beliefs expressed using their framing of personal experience and their recall of events in the news and in their communities. The use of multiple interpretations is intended to help minimize biases from each individual analyst, and also to eliminate the sort of deep personal connection that can develop in an interview when the ethnographer empathizes and that symbolic membrane between them becomes too porous to the point that the cultural models begin to merge. This multiple analyst procedure separates the analysis from the individual respondent in a way that emphasizes underlying cultural knowledge. The progression of the conversation is ordered from broad to increasingly narrow and the respondent is not told in advance what they will be discussing. In that way interviewers can be reasonably confident that the responses are spontaneous. During the interviews I took notes only to keep track of themes, not as a way to document. I kept the interview schedule in front of me but had keypoints highlighted so I only needed to glance down during our conversation to keep track of where we were in the progression. In the next section I describe a few characteristics of three different participants. Each one illustrates a different element of how I worked around the possible downsides of community ethnography and took advantage of the upsides.

\section{Case \#1}

The middle aged man walked toward me where I sat in the shade of an umbrella at the corner of the Starbucks next to the drive through station. The cars idling next to us had their windows rolled up and the heat from the engines moved the still air. It was a sultry summer day, but the music and the chatter of the other customers inside was going to make it hard to record so I staked out a table on the patio in the shade. His wife walked in just a step behind him, and after shaking my hand she went inside. She came back in a few minutes and without a word handed him a Frappuccino and slid into chair at the table next to us. At the time I wondered why she had stayed so nearby, but I was soon swept into conversation with her husband. Later she told me that it was her idea to sign him up to be interviewed for this study. She did it to help the recruiter, who, it happens, is a friend of hers. Small town. And, she also did it to help her husband. She thought it would be good for him, which I understand now. Taciturn is an understatement. He has no children of his own so to reflect on personal experience he went back some 40 years, and that took some thinking. He was raised in a remote county that has a long agricultural history. And that is where he still lives. He has the kind of leathery slightly crinkly skin that comes with long hours in the sun. He worked from childhood helping his family farm. Everything he needed to learn for his career as a mechanic, he learned from working on his parents' tobacco farm-fixing the tractor, hanging out tobacco leaves, looking after livestock. "School was school, but the important stuff came from our farm." Except for his shop class and that is how he got a start as a mechanic. In a way he was the perfect "collaborator." He wanted to be part of the bigger conversation about education, even though he had no obvious vested interest in the outcome. The questions encouraged him to think about something he hadn't thought about in years, and put it into words. Not so easy, but as he told me later, very interesting to him. Talking didn't 
come easily for him. As he and his wife prepared to leave, in a perfect "doorknob" moment, that moment where, metaphorically speaking, her hand was on the doorknob as if preparing to leave, she instead sat down next to me in a familiar way that is rare here in Knoxville, where people are often more reserved until they "figure each other out." She asked me about my name which is a combination of a Swedish first name and a German last name. She tells me she was born and raised in Germany and in 1970 she immigrated with her family at age 15 to Madison County where no one at school had ever met a German. She tells me that she did everything to strip away all remnants of a German accent. Though her mannerisms were a little different the accent was the distinct prosaic lilt of the East Tennessee mountains. She and her husband had only been married five years when I met them. Learning about her background was a neat bonus for me. It wouldn't be part of the transcription so it wouldn't contribute to building the mental models, because the tape was off. And it didn't change my understanding of his comments. But there had been something in the way the two of them came in together and the way she introduced herself to me and then sat nearby during the interview that made take notice and told me there was something unusual about them that led me to pace my questions differently and to not let the external cues of his gate, his dress, his deeply tanned, farmer's skin in early summer drop him in a box labeled Madison County Tobacco Farmer. His silences were expansive! Shy? Thoughtful? Confused?

\section{Defamiliarizing Tips:}

If something seems to be missing, approach the interview as a brand new never before seen cultural environment. Neglect visual cues that lead to stereotyping.

Take mental note of the institutional building blocks of the participant's life and visualize them - in this case, tractors, mechanics, the school building. Add flesh to the descriptions as if fiction writing until you can take them and anticipate what he might do there.

\section{Case \#2}

With her bobbed gray hair, and her full gathered skirt, I knew from the moment she entered Panera that "she's not from these parts." She talked to me about the long road taken by the now largest public school in the region where her children had been students 10 years ago. Her husband had moved down from Washington DC, a lawyer with the Tennessee Valley Authority. Her neighborhood is known for its many Yankee "transplants" because the homes are older, the streets are treelined, and the property values are closer to those in the northeastern states. One of her sons has moved back north, and the other is struggling to find employment here in Knoxville. She has not taken paid work since arriving in Knoxville but spends lots of time volunteering with organizations that I'm familiar with and where I have acquaintances. My challenge here was to flip the switch that had already activated in my head. People we know in common, changes in the school system, community issues. It was hard to flip that switch back because in Knoxville more than in many other places, small symbols like hair color, clothing, and dialect are indicators that draw people together, or alternatively create a distance. The situation challenged me to not assume that I knew her or to empathize to the point of anticipating. It would be normal in daily life, and she and I might well have been friends. Instead I took that familiarity and turned it on its head encouraging her to challenge her own assumptions and elaborate on her thoughts rather than think I understood. It is the common device used in ethnography of asking the research participant to assume the researcher really doesn't understand because. We use any number of devices to get that dynamic. It doesn't always work, for example one respondent through up her hands in an interview and with exasperation in her voice said, "you really don't know much about this do you?!"

\section{Defamiliarizing Tips:}

Recognize nonverbal symbols that might draw ethnographer closer in a casual encounter. Those signals are starting points not assumptions. Somehow avoid the bonding you might crave.

Hear the sequence of their presentation rather than probing based on shared assumptions. Here I was not at my personal best. I had the visuals in my mind from the school, I even imagined her sons, wondering where they were and whether I knew them. As she mentioned an art center in downtown 
Knoxville, I thought of my friend who had built that center and trained many artists in the community. I confess that I shared her name with the respondent and if memory serves, I think we went onto a brief sidetrack full of accolades about this friend we shared history with. Did I miss a defamiliarizing opportunity? I believe I did. But the interview overall certainly did not suffer because we shared enough cues that she understood what the interview needed and went efficiently through her thoughts. What may have been missed is points of disagreement or counterintuitive notions that she may not have wanted to raise out of concern for the bond we had created. But I will not know.

\section{Case \#3}

It was my fault. I had rejected one of the participants selected by the recruiters (that person was an educator, which disqualified her). I did not notice that the slot given the replacement was a different time. So there I was, sitting at my computer downloading audio files from my little Sony recorder when the phone broke the silence of my empty office. It was the recruiter. The participant had just called him looking for me at the Starbucks where our meeting was scheduled. She'd been waiting 30 minutes. The thought in my mind was, what a patient woman, I would not have lasted that long! I quickly realized what had happened and scrambled to reach the cell phone I had in my notes from the recruiter. She's a soccer mom, as it happens, and she tells me she "lives" in her SUV. The soccer fields where she was headed to meet her daughter after her practice are the same ones where I had spent countless (bored) hours of my life with my own children. Instinct told me to take off my work shoes and put on sneakers and a Puma athletic jacket, and to put on a swipe of lipstick. I jumped in the car and headed down the road past the familiar pastures and pulled in to the parking lot. I grabbed the recorder as she rolled down the window and waved. I smiled to see the red velour hoodie and matching warm up pants. Ha! Good instinct. She opened the passenger door to her Danali SUV, and I climbed up and perched on the passenger's seat. How great! I leaned back and sighed. We chattered away, just the way we soccer moms do. And I hadn't turned on the tape recorder yet. This is the "sigh and commiserate" part of the soccer mom thing. First we bond - number and ages of kids; kids' social and sports commitments; schools. I look at my watch and smile, and then I say, well shall we get started? She touches her hair and I click on the recorder. Our sigh and commiserate discussion turns out to have worked extremely well because it gave me the instant frame of reference. She home schools three children and a fourth one goes to a Christian private school. My home school fear. I silenced that mental tape and listened as she careened through one story after another of the "out of school" educational activities at Dollywood, at the zoo, at Ijams Nature Center, and all around the community joining with other Christian home schooling parents. She told me that she's not comfortable with the public school so her children were withdrawn. "In science class they teach opinion as fact," she said, "and I don't think that's right." Why is it, I asked myself, that when I talk with people in other countries about religious beliefs different than mine, I listen and look for the system and the universality, and hooks begin to distinguish themselves, and cultural models take shape. But when I listen to someone in my town call evolution an opinion, I struggle turn off my internal tape. But I did, and that was the defamiliarization exercise. She continued her reflections on what it is like to learn the school material at the same time as her children are learning. I had asked her if she thought a different subject should be taught along with science and she had never considered that idea before so it helped her think deeply about her beliefs in how science should be taught. The question had thrown open an opportunity for her to put words to her beliefs. I thanked her for her time and for bringing many new perspectives to the conversation and clicked off the tape recorder. But she didn't want to stop talking. When I finally got into my sedan and pulled out of the parking lot I had not driven half a mile before my phone rang. She had just thought of some more ideas she wanted to tell me.

\section{Defamiliarizing Tip:}

This interview was emblematic of a cultural model just waiting to be articulated. The bonding was not a risk - we actually had nothing in common in our present life but I certainly understood her rhythms. The logic in her life was so clear to her because she had not had to step outside her frame much, as indicated by what happened when she did-when she perceived her children to be being badly educated because 
evolution was being taught in science. All she had to do was take over their education. It is interesting that when Frameworks told me about the interviews I had a momentary gasp. I called the client, and wondered if we should exclude home schoolers. The decision was to not exclude them. And that was a perfect example of subjectivity thwarted! It turns out that home schoolers have vast knowledge of the ways to take advantage of non school resources for educating their children, and that is precisely the sort of thing we sought to extract during interviews. So when the participant takes the lead as in situations like this the mental models pour themselves and the more the ethnographer stays out of the way the more learning there is, remarkably, on both sides, as I realized when my phone rang on my drive home.

\section{Consumer as Ethnographer}

In the opening paragraphs I said that clients and research participants will not replace anthropologist/ethnographers. The following demonstration study tested the use of consumers in recruiting information from within their own social networks. But ethnographers played a key role in selecting consumers and in training them for their role as consumer ethnographers studying their own environment.

A research team at Oak Ridge National Laboratory (ORNL) undertook an evaluation of one of the American Reconstruction and Recovery Act (ARRA) era programs for the U.S. Department of Energy (DoE). It was the National Weatherization Assistance Program, which provides financial assistance to those in need to improve the energy efficiency and health condition of their home. As part of the evaluation we sought to learn how information is shared within communities (potentially feeding a viral spread of interest). For this cohort we discovered very little social media activity so we invited the consumers to become researchers and collaborators. Each participant received an incentive payment. In a workshop we practiced open ended interviewing. We helped the consumers think back on their experience with the program. Then we asked them to reflect on how they had communicated that to friends and family. What we asked them to do next was not easy. We asked them to defamiliarize their everyday relationships and to follow set communication topics but to use their normal communication style. Ethnographers do this all the time. On the basis of these consumer ethnographer interviews we found that $46 \%$ of the people interviewed had taken action to contact their local program or make improvements on their own because of casual communication with friends and family (Rose and Hawkins, 2012). It is an important finding for a program that is intended to perpetuate household energy conservation behaviors. It was also a good test of using consumers to gather backyard data. As preliminary study this undertaking did not allow any follow up with the consumer researchers who acted both as members of their community and observers of it. We are well aware that the "quality control" on the sorts of responses that are collected is very limited. Only at the front end, in the workshop, did we have an opportunity to be preemptive in helping the consumer internalize the behaviors associated with good listening, questioning, hearing, and note taking. But as a demonstration project it creates the possibility to extend the method into other arenas. For example, what might be the possibilities of truly creating new empathic and ethnographic ways of thinking and engaging among managers, as we will see in the Client as Ethnographer section?

The Weatherization Experience demonstration project was not strictly speaking business anthropology, so it was an interesting experience because I was able to create something of a bridge to extend methods from the public to the private sector applications of anthropology. Business anthropology has something of a longer history of using consumers to narrow the gap between researcher and consumer. Some ethnographers may remember the at one time highly innovative practice of disposable cameras and journaling by consumers, even beeper studies, first made famous in the Experience Sampling studies of psychologist Csikszentmihalyi (1990). Collaging has a long history as a projective technique, used as a "homework" assignment or in focus group settings for deeper understandings of specific products and brands. There is a proliferation of mobile apps and tools and a growing use of digital ethnography, social media, and phones with cameras and video. All are means for accessing a consumer's point of view and experience. These will only continue to increase as the general population has more 
access to smart phones, wearable technology, the Internet of Things, and applications of all of these that the consumer is often even more ingenious at developing than is the researcher.

\section{Client as Ethnographer}

Clients in consumer ethnographies often ask to shadow ethnographic studies to get closer to the consumer. There are good reasons for them to be included and there are also good reasons for the ethnographer not to want them included. The latter is easily understood as cluttering the field. On the side of advantages to client inclusion there is nothing better for the product and for the company than for management to get firsthand experience (not just through a video or audio recording) of the lives of people who use the products. Typically the material the client is looking for is not like the applied communication research, which results in constructing a consumer's mental model. Rather the lived experience through story telling is the goal, and often the innovative mind of the user, as von Hippel et al. have documented (Von Hippel, 2003) in the age of the consumer innovator, documenting actual and innovative uses among consumers of existing products - particularly commonplace with computing technology. But there are constraints that this backyard ethnography discussion alerts us to. Clients, particularly in leadership, hold opinions of their product's "real" users and may feel a sort of ownership of the relationship. At that point the line from observation to socializing is crossed-That symbolic membrane separating consumer cultural models from researcher models is lost and the consumer model may be subsumed into the client's assumptions. The work around many ethnographers will use in such to protect the data is to create a special window of opportunity for the client to follow on with questions not covered. And that is what we did in this case of client shadowing for a fast food client.

The client's challenge was to find a way to increase the sales of their burgers among the group who were already real devotees of the brand. The study, conducted in several cities, consisted of in home ethnographies and visits to several fast food restaurants (the client was anonymized). The method was new to the client and many consumer ethnographer readers will recognize in this the client who is not just seeking to learn about the consumer but also to learn some of the techniques of participant observation. The research team had worked with the client for over a year so it was agreed each ethnographer would take one member of the client team to the field. As mentioned in the paragraph above in the section on Consumer as Ethnographer, it's a good idea to have a plan. Here was where we began:

A brief tutorial was offered to explain how ethnography can be most successful--

- Be as non intrusive as possible-follow the respondent's lead on what is important to them

- Make a social connection but do not allow your own personal narrative to get in the way

- Be friendly but don't "make friends" - that's the bonding issue that I encountered in the Community Ethnographies

Field logistics--

- The team consists of two people: the ethnographer and the client

- A request for an additional person from the client side was turned down because there's not enough space; the explanation was that because the study involved a drive to a fast food restaurant in the client's car, if the car was too small the logistics would slow the project down

- The study included videotaping-the client was given the responsibility of holding the video camera, and that way they were always a valued member of the team

- The client was introduced as the camera person and a member of the team, not as the client

- At predetermined moments if the ethnographer would check in with the client to see if they had topics that hadn't been addressed or if they were just curious about anything that had been brought up. If so the client hands the camera to the ethnographer.

How did all this work? Not stellar in the field. There is an irresistible urge to bond. Sometimes the client was seen to step outside their "client" persona and a feeling of who's cooler would lurk. We speculated that might have something to do with the sense of authority the client feels, but it is also clearly the pride of ownership over the brand because of their dedication to the work over a long span of 
time, versus the relatively short engagement that the ethnography team typically has. However, in the project experience, when we ethnographers gathered in evenings with the client the dinner conversation bubbled over with insights and experiences, anecdotes, surprises, and new understandings. Just the sort of thing ethnographic observations are intended to arrive at, so the added challenge of bringing a client to a deeper understanding of what it is to be and think ethnographically among consumers of the client's product is critical. The higher the level of management, moreover, the more avenues of communication that client has to convey understandings within the company about who the products and services are being developed for. And in the case of this study, there were more studies designed for our team in direct consequence of the growing appreciation for what is to be learned. Stories in the consumer and market anthropology community abound, though, of gaffs or awkward moments with clients in the field. Is it worth it? Each case must be assessed individually and the "boot camp" or tutorials designed as needed.

\section{DECONSTRUCTING PARTICIPANT OBSERVATION}

I believe that one of the biggest challenges we are presented with when extending ethnography into the consumer and the client driven modes has to do with the unexamined nature of observation itself (and of course participation as well, as indicated by the nearly irresistible urge to bond). What is it that we do when we are seeing things around us, and I refer the reader back to the unlinking of name and image by Magritte in the paper's epigraph? As I delve into how we perceive, and by that I mean more than just see, but "take note," and mark as important, I also refer to the recognition of what we carry into our observation - the biases and subjectivities we've been talking about. The unexamined and tacit knowledge that is extracted by a skillful interview is also embedded in the interviewer and frames the sorts of things seen and noted.

The backyard, metaphorically, is anything that is in a researcher's comfort area. It could be we're engaged with clients and participants in the study of technology we have close working knowledge of; or that we share a life stage or role like home owner, or parent. That used to be called rapport, so in a way this is not new at all. It's perhaps a new take on using our positioning, and carefully placing it in the ethnographic experience with enough self-awareness that we don't make assumptions about the degree of shared understandings. Being able to do that well, without directing, or monopolizing, that is part of the super power that a good ethnographer possesses. The cases from the Community Interviews illustrate how theory of culture and cognition combine with "instinct" about meaningful patterns. Collaborative ethnography casts the consumer or the client as that backyard ethnographer, gathering knowledge from within their communities, or in the case of a client shadowing an ethnographer and observing sometimes for the first time, the consumer with the product.

In the introduction I mentioned that I worried about my biases on the topic of education, a very delicate topic here in East Tennessee, the buckle of the Bible belt. I wondered if my biases would show. I hold dearly to the idea that education is evidence and science based, and that religion is valuable but that it is practiced in spiritual communities not in schools. I have long noticed that I have different ways of taking in new experiences in other countries where my mind is busy trying to build the mental models of those around me, vs in the US where I consider myself at home and hold to "my ways." Elsewhere I am not bothered by invitations to people's churches like when I did research in the Caribbean; in the US I feel proselytized to. Elsewhere I try new foods even if I think they're unhealthily loaded with sugar or unidentifiable ingredients like, like bubble tea in Singapore for example. But I was also concerned about making assumptions about participants who were more aligned with me ideologically. But I was also excited to be in a place where I know the community, the landmarks and the history and can bring experience and perspective to a more immediate understanding the participant's point of view. To be clear, I don't come from East Tennessee, so I bring something of an outsider's view even while being at home here for many years. This is a town that has not integrated new comers easily, as one could guess from the newly formed Knoxville New Yorkers Meetup group with members who have lived in Knoxville for decades. Will I carry an internal dialogue into my interviews? Will I assume things I shouldn't? Or perhaps be able to use it to my advantage for a more critical ear that hears better? 


\section{Observer}

An internal dialogue can interfere with perception - feeling, seeing, smelling, hearing. An observer is never free of tacit knowledge, memories, assumptions, all of which influence perception. Observation is influenced by what we already know and how we define importance. Even the fact of observation is culturally determined. Not perceiving happens because it is so familiar we take it for granted or so novel we have no cultural model, or cognitive hooks to make sense of it. Either way one is blind.

\section{Observation: blinded by the familiar}

Observation is the part of participant observation we rarely talk about, perhaps because it is taken for granted as a physiological process and we have sold short the cultural dimension. In fact it is a core cognitive and symbolic process. It consists of perceiving, representing, interpreting, analyzing, and then returning to test the initial perception. It is a dialectic. As cognitive scientist, Marvin Minsky, a pioneer of artificial intelligence noted, "a theory of seeing should also be a theory of imagining" (Minsky, 1974). Perception also includes what is missed by the observer who decides it is not meaningful, or is distracted, or doesn't recognize a variant. Or in fact the perceptiveness to notice what is missing, or not said. Habit is the culprit preventing us from seeing and hearing. Contemporary poets, novelists, musicians, dancers and artists are superb observers. Their eyes and ears break the barriers to observation that habit creates. John Cage, the $20^{\text {th }}$ century experimental composer wrote a piece called 4 ' $33^{\prime \prime}$ in which the musicians come on stage without playing a note, and the music that the audience hears is the environment - the sounds they create. Music is all around us, he said, if only we have ears to hear (Cage, 1961). The art of perception is dulled by over familiarity, as medical practitioners in cardiac units know well, from studies of "alarm fatigue" linking overuse of alarms to higher incidences of unheeded cardiac distress (Knox, 2014). Anthropology teaches us to break the barriers that habit creates by looking across cultures. That's when everything is said to be noticeable because it is different and unaccustomed. It sounds like music and looks like art and feels like poetry. A good interview can help find the unfamiliar in the everyday without leaving home.

\section{Observation: Blind because of the unfamiliar}

But there are limits to perceiving the unfamiliar. If there are no cognitive hooks on which to hang new knowledge then sense making is difficult and it is impossible to distinguish what is meaningful from what is not. Many business anthropologists know the at-sea feeling that characterizes the start of new research in unfamiliar countries, a user experience study of new technology, or the study of an organization with no org chart. The learning curve is steep, but not impossible. Cognitive and psychological anthropologists have addressed the issues of learning without lattices on which to build and interpret new experiences. Cognitive anthropologist Bradd Shore (Shore, 1991:21) explains that perception depends on what he calls the second birth of an existing cultural model. The first birth is defined by culture and it exists in social context but for the individual to feel comfortable, they need time and motivation to internalize the cultural model. That is the second birth, more commonly called enculturation. A cultural model exists twice, once in society and eventually also in the individual. It encodes familiar behavior, complete with belief system, and modes of practice. For someone not raised or at least experienced in that cultural environment, perception, understanding, even memory and recall can be flawed or even impossible until they internalize that model and it becomes part of them. So if a person is lacking a cultural model, they may also be lacking the ability or the desire not only to understand but maybe even to see, as in the mythic story of Meso Americans' inability to "see" Columbus's ships approaching, but for the parting of the waters (I mention the Meso American image as symbolic of that rich point where we struggle to articulate new cultural knowledge. It was told to me by one of the study participants representing the Tribe whose access to spiritual value in an undisturbed river were at risk because of a licensing request for hydroelectric power. He said you don't understand because you don't have any frame of reference, just like when Columbus's ships approached). 


\section{DEFAMILIARIZE THE BACKYARD, BUSINESS IMPLICATIONS}

I realize that all business anthropology is backyard ethnography in the sense that the collaborators carry stereotypes, subjective biases and opinions, and especially hopes and visions for the product or service for which the research is conducted, not to mention a vested interested in growth and sales. These biases can result in blindspots within the organization about whose perspectives are heard and how and whether the consumer's concerns are reflected. Moreover the biases and visions of management can result in corporate blindspots about the sourcing of materials (business as usual) and about the supply chain itself including the possibility of bad labor practices and human rights abuses. The deeply examined vignettes and tips for defamiliarizing what is in front of us presented in the Community Ethnography section tell us not just that we should take the client to the field and listen to the consumer, but that management and staff within organizations can apply these very tools (frameworks and tips) on themselves as means to unlock business as usual and hunt down the assumptions that impeded good business.

Companies of all sizes and in all sectors are challenged to remain relevant to consumers as they are outpaced by changes in the marketplace, say for example the shift to mobile and "cloud computing" or the increased relevance of big data and analytics, the role of social media and word of mouth marketing. Trends like these require that companies reinvent their brand, transform ways of doing business, create new products. Likewise, shifts in public concerns about the world we live in - sustainability, waste stream reduction and accountability, supply chain and labor conditions. Issues often grouped as Corporate Social Responsibility (CSR) become mandatory for the survival of a brand. To understand what matters to the consumer in changing times and to respond to new market place demands with new ways of doing business, some corporations are turning to anthropology and the use of ethnographic methods. Others are taking it upon themselves to restructure according to these changes (for example the new Microsoft CEO, is an expert in cloud computing). A beverage company is considering hiring managers adept in social media because they're plugged in to the consumer, and because it will "free the management team from "well rehearsed habits" (Harryson et al 2014:2). A global advertising firm uses the digital economy as the field of research, creating an "anthropological view" out of snippets plucked from social media to identify a product opportunity (Harrysson et al, 2014:2). Being freed from "well rehearsed habits" is the practice of defamiliarization. As the Harryson et al article notes, managers who repeat common practices because it is tacitly "known" as the best practice, can fall into traps, which they indicate, can be broken by allying themselves more closely with the consumer point of view by tracking what is posted in the social media. Popular news publications and trade journals have taken note of this kind of anthropological thinking and of the direct role of anthropologists in business (an online search of the key terms anthropology, ethnography, consumer research, will produce commentary and articles in the likes of Wired, Atlantic Monthly, McKinsey Quarterly, MIT Sloan Management Review, Harvard Business Review, Financial Times, The Economist, The New Yorker, O! the Oprah Magazine, and many others).

\section{CONCLUSIONS}

Though my initial pursuit in examining the vignettes from the Community Ethnography for this paper was to challenge the limitations of working in familiar settings and to in fact bring to light its benefits, the metaphor of the backyard when extended to environments that are familiar, made it clear that people within organizations can internalize ethnographic ways of thinking, and that was seen in the Client as Ethnographer discussion when consumers collected anecdotes from friends and family about impressions and knowledge of weatherization experiences. Also in the Consumer as Ethnographer section where clients were often challenged to keep their opinions to themselves and to entertain new models of knowledge about the product that they had. In those circumstances the "ethnographers" will be faced with the very challenges I was faced with of unearthing our biases and questioning things as if they were unfamiliar. It is with a sense of urgency, that I suggest we continue to encourage people in consumer and management research to use the tips and methods identified here to help clients turn the ethnographic lens 
on themselves and to listen clearly and perceive openly the consumer point of view. With the options proliferating for ways to connect more directly with consumers in business and with management in corporate structure business anthropology has contributions to make in guiding the ethnographic process even while not controlling every aspect of data collection. The three Community Ethnography cases as well as the Consumer as Ethnographer section demonstrate coexistence in a single ethnography of backyard familiarity and defamiliarization, as natural components of perception. Objectivity is not the goal of business ethnography, so the concern with which the paper opens, of the influences from the participant's position in a community and the constraints from observation in overfamiliar settings and circumstances are not enough to refrain from bringing the client and the consumer into research, in the increasing modes available.

\section{ACKNOWLEDGEMENTS}

Thanks go to the Ken Erickson for a careful review and for turning me on to a couple of new writers in the backyard ethnography field. Thanks also to Nat Kendall-Turner of the Frameworks Institute whose excellent and incisive interview structure inspired the writing of this paper. I alone am responsible for any errors in conveying the theoretical foundations of the interview method. Thanks also to Bruce Tonn, Erin Rose, and Beth Hawkins of ORNL' inspired Weatherization Experience team for the opportunity to help develop and carry out some truly innovative work in anthropology and in the field of consumer side energy knowledge and consumption. I hope to see more work like that from DOE in the future, as it melded knowledge from many sources and integrated recommendations that may, I hope, lead to reduced energy dependency, and to healthier and more comfortable homes across the US.

\section{REFERENCES}

Bosch, T.E. (2007). Confessions of a backyard ethnographer. 21 May, 2007. http://blogs.uct.ac.za/blog/teblog/2007/05/21/confessions_of_a_backyard_ethnographer (accessed June 21, 2013).

Cage, J. (1961). Silence. Middleton, CT: Wesleyan University Press.

Cembalest, R. (2012). This Is Not a Pipe-But It IS a Newly Discovered Magritte. ArtNEWS.

Clifford, J. \& Marcus, G.E. (eds.). (1986). Writing Culture: The Poetics and Politics of Ethnography. Berkeley: University of California Press.

Csikszentmihalyi, M. (1990). Flow: The Psychology of Optimal Experience. New York, NY: Harper and Row.

Fisher, M.J. \& Marcus, G.E. (eds.). (1986). Anthropology as Cultural Critique. Chicago: University of Chicago Press.

Harrysson, M., Métayer, E. \& Sarrazin, H. (2014). The strength of 'weak signals.' McKinsey Quarterly. http://www.mckinsey.com/Insights/High_Tech_Telecoms_Internet/The_strength_of_weak_signal s?cid=other-eml-alt-mkq-mck-oth-1402. Retrieved February 11, 2014.

Holland, D. \& Quinn, N. (1987). Cultural Models in Language \& Thought. Cambridge: Cambridge University Press.

Jackendoff, R. (1985). Semantics and Cognition. Cambridge: MIT Press.

Keller, C.M. \& Keller, J.D. (1996). Cognition and Tool Use; The Blacksmith at Work. Cambridge: Cambridge University Press.

Knox, R. (2014). Silencing Many Hospital Alarms Leads To Better Health Care. http://www.npr.org/blogs/health/2014/01/24/265702152/silencing-many-hospital-alarms-leads-tobetter-health-care, January 27, 2014. retrieved January 31, 2014.

Magritte, R. (1929). Les mots et les images. La Revolution Surrealiste 12, 32-33.

Mclaughlin, E. \& Kraus, N. (2003). The Nanny Diaries: A Novel. NY: St. Martin's Griffin. 
Minsky, M. (1974). A Framework for Representing Knowledge. MIT-AI Laboratory Memo 306. http://web.media.mit.edu/ minsky/papers/Frames/frames.html (retrieved January 31, 2014). Reprinted in Mind Design, J. Haugeland (ed.) (1981). Cambridge: MIT Press.

Ortlieb, M. (2013). Introductory remarks to EPIC session, (Co)creation and (Co)participation. Conference Proceedings of EPIC2013 London. American Anthropological Association.

Peshkin, A. (1988). In Search of Subjectivity--One's Own. Educational Researcher. 17(7), 17-21.

Rose, E. \& Hawkins, B. (2012). The Weatherization Experiences Project: Preliminary Findings; paper prepared by Oak Ridge National Laboratory, Environmental Sciences Division, as tasked by the United States Department of Energy, presented at The Behavior, Energy, and Climate Change Conference. http://beccconference.org/wp-content/uploads/2012/11/becc_2012_abstracts.pdf.

Shore, Bradd. (1991). Twice Born Once Conceived: Meaning Construction and Cultural Cognition, American Anthropologist 93 (1), 9-27.

Sunderland, P.L. \& Denny, R.M. (2007). Doing Anthropology in Consumer Research. Walnut Creek, California: Left Coast Press.

Treitler, I. (1996). Culture and the Problem of Universal Access to Electronic Information Systems. Social Science Computer Review, Vol. 14(1), 62-4.

Treitler, I. (1994). Tribal and Agency Strategies for Assessing Impacts. In Federal Law, Native Americans, and Cultural Resources: Practicing Anthropology, I. Treitler and R. Stoffle, (eds.). 16(3).

Van Maanen, J. (2011). Tales of the Field: On Writing Ethnography, second edition. Chicago: University of Chicago Press.

Von Hippel, E., Ogawa, S. \& de Jong, J.P.J. (2011) The Age of the Consumer-Innovator. MIT Sloan Management Review, Magazine: Fall 2011. http://sloanreview.mit.edu/article/the-age-of-theconsumer-innovator/, retrieved January 31, 2014.

Yang, C. (2009). Doing 'ethnography at home.' www.kvinfo.su.se/femmet09/papers/pdf/Yang.pdf. Retrieved July 6, 2013. 